\title{
THEORETICAL GROUNDING OF ENVIRONMENTALLY BALANCED STRATEGY OF AGRARIAN ENTERPRISE DEVELOPMENT
}

\author{
Kateryna Nyzheholenko \\ Agricultural Meliorations and Environmental Economics Department \\ Kherson State Agrarian University \\ 23 Streetenska str., Kherson, Ukraine, 73006 \\ v-barmira@ukr.net
}

\begin{abstract}
In the article is given the assessment of environmental balance of economic development of agrarian enterprise, the aims of enterprise were elaborated, and their positivity was verified. There was graphically built the "tree of aims" for realization of environmentally balanced strategy of PRAE Agro-firm "Mir". It was scientifically grounded, that all aims and correspondent conditions that provide their attainment are devoid of conflict.

Keywords: economic development, agrarian enterprise, environmental and economic potential of enterprise, environmentally balanced strategy of enterprise.

\section{Introduction}

Strategic precondition of development of the country, region or separate enterprise as socio-economic systems of the different hierarchical levels is a maximal use of their social, economic and environmental potentials. At the same time the logical result of incoherence of strategic aims of the state, regions and enterprises and absence of the united scientifically grounded approach to the mechanism of developmental strategies formation is an appearance of "hybrid" forms of economy and management that are formed of the heterogenic elements and have many internal contradictions [1].

For today for most agricultural enterprises the sphere of strategic management is more complicated and needs detailed study. The study of the features of formation of environmentally balanced strategy of enterprise development needs the special attention.

\section{Review of the main sources and publications}

Theoretical problems, connected with general processes of environmental management, especially, with processes of eco-management formation at enterprise level were studied [2-4]; strategic directions of attainment of environmentally balanced nature management were formed [5]; scientific-methodological approaches to the formation of environmentally oriented strategies of enterprise development were offered [6-8]; regions with stressful environmental state as a result of irrational use of natural-resource potential and excessive technogenic load of environment were studied [9]; significance of environmental management in the system of management of the balanced development were analyzed [10]; long-term strategy of the stable development of agroindustrial development was proved [11].

\section{Aim and task of research}

The aim of article is the study of theoretical bases of formation of environmentally balanced strategy of agrarian enterprise development.

For attaining this aim the following tasks were set:

1. To carry out the assessment of natural-resource potential and environmental balance of economic development of agrarian enterprise.

2. To elaborate the aims of enterprise and to verify their positivity.

3. To build the "tree of aims" for realization of environmentally balanced strategy of PRAE Agro-firm "Mir".

4. To formulate the mission of agrarian enterprise.

5. To take into account the regional features of environmental balance. 


\section{Materials and methods of research}

In researches were used the methods of induction, deduction, comparative analysis, integral assessment of environmental direction of enterprise that allows define the main vectors of ecologization of enterprise agricultural activity [5].

\section{Results of research}

The aims of enterprise were elaborated and their positivity was verified, the "tree of aims" for realization of environmentally balanced policy of PRAE Agro-firm "Mir" was graphically built. It was proved, that all aims and correspondent conditions that provide their realization are devoid of conflict. Thus, the "tree of aims" itself is devoid of conflict and can become the base for establishing the mission of studied enterprise.

\section{Discussion of the results}

The sphere of agrarian nature management like nothing else feels now the need for elaboration of the strategies of environmental balancing of economic development on the base of system analysis and methodological approach. That is methodological base of research is the complex and system approaches and also dialectic method of cognition of connection between processes in the system of environmentally balanced development of agrarian enterprise and elaboration of strategy of making environmentally oriented managerial decisions as to minimization of anthropogenicthechnogenic influence on environment [5].

In elaboration of environmentally balanced strategy and mission of enterprise the initial stage is a definition of aims of enterprise activity. The mission of agrarian enterprise it is the main aim of it, the production of eco-friendly products for satisfying the market needs and gaining the maximally possible profit at that.

Aims are the final results of enterprise that leaders and labor collective strive to in all spheres of activity at the end of strategic period. So, enterprise faces with aims, which attainment provides strategic advantages over competitors. They must be formulated depending on the actual problems of enterprise. Agrarian enterprise faces with the series of aims as to its environmentally balanced development, which attainment provides strategic advantages over competitors, namely:

- widening of sales markets of eco-friendly production;

- cultivation of eco-friendly agricultural production;

- cultivation of medical plants;

- introduction of resource-saving technologies;

- preservation and further development in animal breeding;

- guaranteeing of favorable environment, infrastructure and conditions for labor, leisure and physical development of rural population;

- introduction of instruments of environmental-economic stimulation of landowners as to environmentally balanced agricultural activity;

- introduction of eco-friendly agricultural meliorations;

- ecologization of production processes;

- introduction of eco-marketing;

- improvement of image of enterprise as an eco-friendly one;

- diversification of economic activity in directions of environmental safety.

Strategic planning includes realization of strategic aims that must be concrete and measured with the help of determined criteria. Six types of aims for attaining the environmentally balanced strategy of agrarian enterprise development can be separated:

1. Ecological aims. Diminution of the negative influence of economic activity on environment.

2. Innovative aims. Investment of innovative technologies of cultivation of agricultural plants, obtaining of eco-friendly agricultural production.

3. Resource aims characterize aspiration of organization for eco-friendly and economically balanced use of the resource possibilities of region and enterprise. Introduction of eco- 
marketing for finding resource-saving technologies, technique and species of agricultural plants on the market.

Aims of rise of environmental, economic and social effects of economic activity:

1. Social aims, directed on creation of eco-friendly conditions for the life of population and preservation of bio-diversity.

2. Aims of gaining the determined profit can be established only after formulation of previous aims. The profit can help to involve capital for ecologization of agricultural activity.

The strategy of enterprise activity is elaborated depending on the offered aims and mission of agrarian enterprise in direction of its environmentally balanced development (Fig. 1).

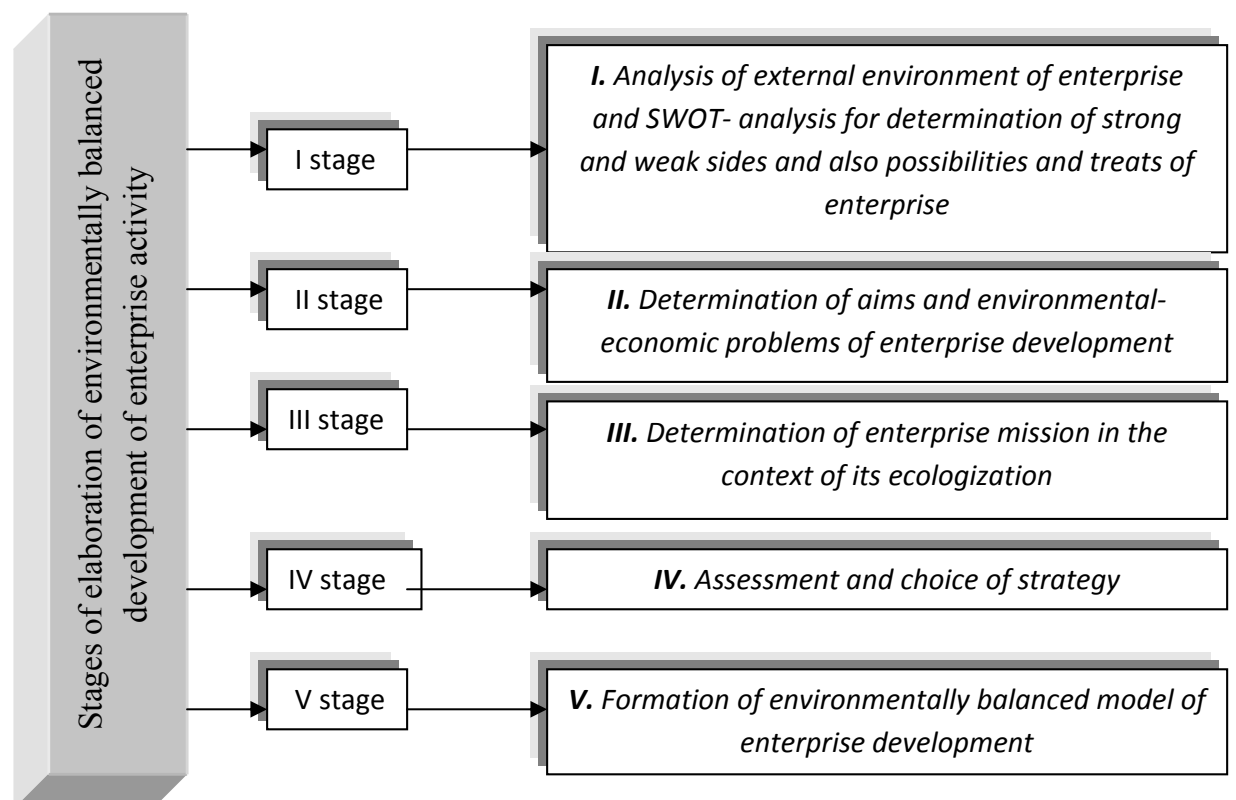

Fig. 1. Stages of elaboration of environmentally balanced development of enterprise activity

The system of aims is a base of formation of enterprise mission. But it is unreal task to attain all aims at once even in the long period of time, because leaders distribute the limited resources irrationally. This condition can be prevented by the choice of priorities in work and outlining of providing conditions for attainment of each concrete aim. For that we use the building of the "tree of aims". This process includes:

Step 1 - formulation of aims. The aforesaid aims are the general ones, so it is necessary to concretize them.

Each of the offered aims favors providing of eco-friendly mission of enterprise, so it can be presented by the directions of agrarian enterprise activity. The process of formation of environmentally balanced mission and strategy we consider on the example of agricultural enterprise AF "Mir" of Novotroitsky district, Kherson region (Table 1).

Step 2 - determination of aims priorities.

The given directions of activity must be assessed by the priority of their achievement and the optimal ways of the further environmentally balanced development must be selected from the whole number of alternatives (Table 2).

Each aim, determined by each factor in the Table 2, is a style aim, on the "tree of aims" (Fig. 1) it will be marked as $\mathrm{C}_{1}, \mathrm{C}_{2}, \mathrm{C}_{3}, \ldots, \mathrm{C}_{7}$.

Each of these aims, in its turn, needs establishing of providing conditions and choice of priority of its attainment. That is why on the Fig. 2 is presented the "tree of aims" for realization of environmentally balanced policy of PRAE Agro-firm "Mir". 
Table 1

Factors (conditions) that provide the attainment of environmentally balanced mission of PRAE AF "Mir"

\begin{tabular}{|c|c|c|}
\hline Factor & Current potential of enterprise & Desired potential of enterprise \\
\hline $\begin{array}{c}\text { Ecologization } \\
\text { of organizational } \\
\text { structure of management }\end{array}$ & Linear-functional structure of management & $\begin{array}{l}\text { Creation of functional subsections in organizational } \\
\text { structure: eco-marketing and eco-management }\end{array}$ \\
\hline $\begin{array}{l}\text { Organization } \\
\text { of environmental- } \\
\text { economical production }\end{array}$ & $\begin{array}{l}\text { Production of eco-friendly products of plant growing and } \\
\text { animal breeding }\end{array}$ & $\begin{array}{l}\text { Innovative technologies of cultivation } \\
\text { of agricultural plants }\end{array}$ \\
\hline Financial management & $\begin{array}{l}\text { High solvency and liquidity of enterprise, partial dependence } \\
\text { from external financial sources }\end{array}$ & $\begin{array}{l}\text { Possibility to introduce resource-saving and } \\
\text { eco-friendly technologies of cultivation of agricultural } \\
\text { plants and high-quality production }\end{array}$ \\
\hline $\begin{array}{l}\text { Eco-marketing } \\
\text { and management }\end{array}$ & $\begin{array}{l}\text { The system of preparation of staff in direction of ecologization } \\
\text { of economic activity of agrarian sector of regional economy }\end{array}$ & $\begin{array}{l}\text { Ecologization of both system of management and the } \\
\text { whole economic activity }\end{array}$ \\
\hline Social & $\begin{array}{l}\text { Proper eco-friendly conditions of labor, leisure, physical } \\
\text { development of rural population }\end{array}$ & $\begin{array}{l}\text { Improvement of labor conditions as to the season } \\
\text { workers, provision of their life activity and food }\end{array}$ \\
\hline Organizational & $\begin{array}{l}\text { Support of existent type of linear-functional structure } \\
\text { of the management }\end{array}$ & $\begin{array}{l}\text { Purchase of the new equipment and creation } \\
\text { of the new workplaces }\end{array}$ \\
\hline $\begin{array}{l}\text { Technological } \\
\text { and innovational }\end{array}$ & $\begin{array}{l}\text { Successive refill and introduction of the new technique and tech- } \\
\text { nology for cultivation of eco-friendly agricultural production }\end{array}$ & $\begin{array}{l}\text { Establishing of cooperation with scientific institutions, } \\
\text { research stations and selection centers }\end{array}$ \\
\hline
\end{tabular}

Table 2

Choice and assessment of providing conditions for environmentally balanced development of PRAE AF "Mir"

Factor

Conditions

Aim: Creation of sections of eco-marketing and eco-management and market study of their effectiveness

Organization of enviEcologization of both system of management and the whole economic activity

Introduction of resource-saving and eco-friendly technologies of cultivation of agricultural plants and

high-quality production

Cultivation of medical plants

Aim: Capitalization of $5 \%$ of annual profit of enterprise for ecologization of agricultural activity

To carry out marketing studies for finding the eco-friendly technologies, raw materials and species of

\begin{tabular}{|c|c|c|}
\hline \multicolumn{3}{|c|}{ Aim: Capitalization of $5 \%$ of annual profit of enterprise for ecologization of agricultural activity } \\
\hline \multirow{2}{*}{ Eco-marketing } & $\begin{array}{l}\text { To carry out marketing studies for finding the eco-friendly technologies, raw materials and species of } \\
\text { agricultural plants on the market }\end{array}$ & 2 \\
\hline & $\begin{array}{l}\text { Finding of the segment for realization of eco-friendly production on agricultural market and conquest of } \\
\text { the new sales markets }\end{array}$ & 4 \\
\hline \multicolumn{3}{|c|}{ Aim: Access to the new sales markets; widening of the market part by $5 \%$. } \\
\hline \multirow{4}{*}{$\begin{array}{l}\text { Financial manage- } \\
\text { ment of environ- } \\
\text { mentally balanced } \\
\text { activity }\end{array}$} & Investment of innovative technologies of cultivation of agricultural plants and high-quality production & 1 \\
\hline & Financing of preparation of specialists for providing ecologization of economic activity & 2 \\
\hline & Use of environmental-economic instruments for stimulation of ecologization of economic activity & 3 \\
\hline & Investment of innovative technologies for cultivation of medical plants & 4 \\
\hline \multicolumn{3}{|c|}{ Aim: To analyze indices of liquidity and solvency quarterly during $2-3$ years } \\
\hline \multirow{3}{*}{ Social } & $\begin{array}{l}\text { Organization and holding of holidays for enterprise workers and village dwellers (for example, "Day of field") } \\
\text { with encouragement and rewarding of the better workers }\end{array}$ & 3 \\
\hline & Active participation in agricultural expositions, seminars and so on & 1 \\
\hline & Improvement of labor conditions as to provision of season workers with conditions of life activity and food & 2 \\
\hline \multicolumn{3}{|c|}{ Aim: To create the proper conditions for enterprise workers and village dwellers, activate the public activity } \\
\hline $\begin{array}{l}\text { Technological and } \\
\text { innovative }\end{array}$ & $\begin{array}{l}\text { Successive refill and introduction of the new technique and technology for cultivation of eco-friendly } \\
\text { agricultural production }\end{array}$ & 1 \\
\hline \multicolumn{3}{|c|}{$\begin{array}{l}\text { Aim: Establishing of cooperation with scientific institutions, research stations and selection centers, trade representatives of the famous } \\
\text { foreign companies to purchase the foreign technique }\end{array}$} \\
\hline \multirow{3}{*}{ Organizational } & Provision of enterprise with staff, qualified in the field of biological sciences, agronomy and so on & 1 \\
\hline & To move at the new stage of organizational structure of management & 2 \\
\hline & $\begin{array}{l}\text { To give a possibility of practice to the specialists-beginners in existent laboratory of production of anti-tumor } \\
\text { preparations }\end{array}$ & 3 \\
\hline
\end{tabular}




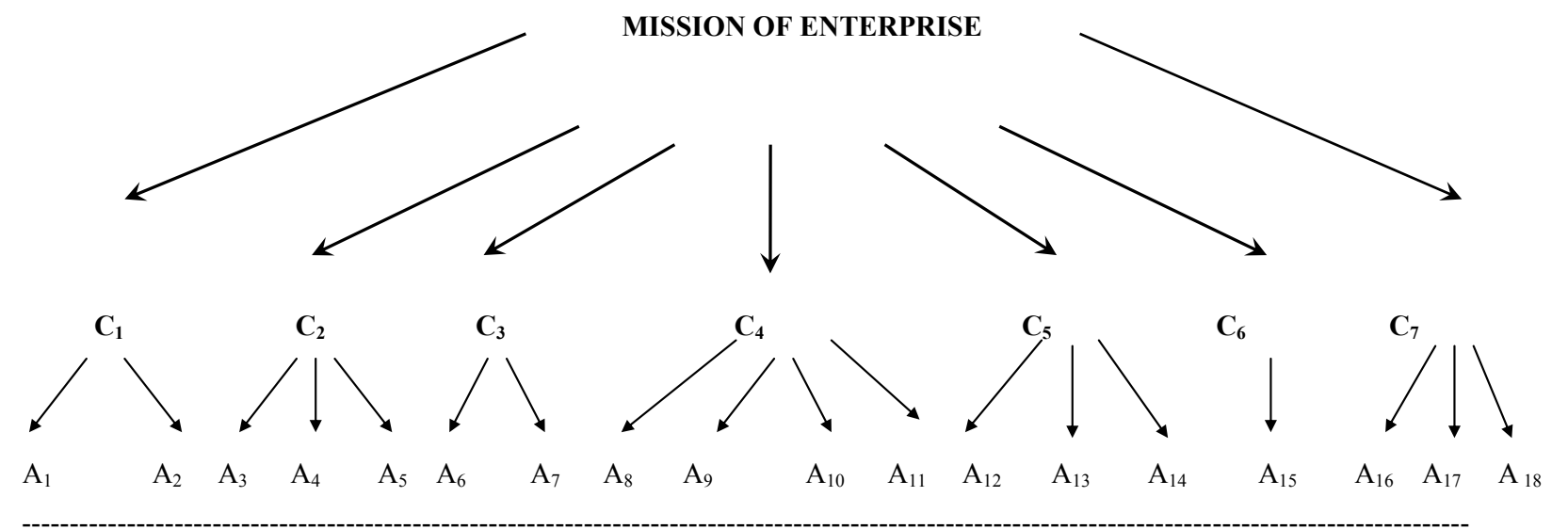

Fig. 2. "Tree of aims" for realization of environmentally balanced policy of PRAE Agro-firm "Mir"

Each of these aims, in its turn, needs establishing of providing conditions and choice of their priority for attaining the aim. On the Fig. 2 of "tree of aims" under the dotted line let's assess the weight of each separate working aim.

Step 3 - check of aims for positivity.

The next step after graphical building of the "tree of aims" is a check of aims on positivity. Revelation of the negative consequences of attaining the aims is in establishing of the relationship of incompatibility between aims and conditions that provide their attainment. For that the matrix "aims-providing conditions" is created for each level of the "tree of aims". It is the following (Fig. 3).

\begin{tabular}{|l|l|l|l|l|l|l|l|}
\hline & $\mathrm{C}_{1}$ & $\mathrm{C}_{2}$ & $\mathrm{C}_{3}$ & $\mathrm{C}_{4}$ & $\mathrm{C}_{5}$ & $\mathrm{C}_{6}$ & $\mathrm{C}_{7}$ \\
\hline $\mathrm{A}_{11}$ & +1 & & & & & & \\
\hline $\mathrm{A}_{12}$ & +1 & & & & & & \\
\hline $\mathrm{A}_{22}$ & & +1 & & & & & \\
\hline $\mathrm{A}_{21}$ & & +1 & & & & & \\
\hline $\mathrm{A}_{23}$ & & +1 & & & & & \\
\hline $\mathrm{A}_{32}$ & & & +1 & & & & \\
\hline $\mathrm{A}_{31}$ & & & +1 & & & & \\
\hline $\mathrm{A}_{41}$ & & & & +1 & & & \\
\hline $\mathrm{A}_{42}$ & & & & +1 & & & \\
\hline $\mathrm{A}_{43}$ & & & & +1 & & & \\
\hline $\mathrm{A}_{44}$ & & & & +1 & & & \\
\hline $\mathrm{A}_{53}$ & & & & & +1 & & \\
\hline $\mathrm{A}_{52}$ & & & & & +1 & & \\
\hline $\mathrm{A}_{51}$ & & & & & +1 & & \\
\hline $\mathrm{A}_{61}$ & & & & & & +1 & \\
\hline $\mathrm{A}_{71}$ & & & & & & & +1 \\
\hline $\mathrm{A}_{72}$ & & & & & & & +1 \\
\hline $\mathrm{A}_{73}$ & & & & & & & +1 \\
\hline
\end{tabular}

Fig. 3. Matrix "aims - providing conditions"

All aims and correspondent providing conditions for their attainment are devoid of conflict. Thus, the "tree of aims" itself is devoid of conflict and can become the base for establishing the mission of studied enterprise.

The last stage is a formulation of environmentally balanced mission of enterprise.

Taking into account these factors, the directions of activity are reflected in mission and responsibility of enterprise to the all influence factors is stated. It distinctly determines the general aim of enterprise that can be in further concretized on the separate aims and problems. 


\section{Conclusions}

As a result of researches:

1. The assessment of natural-resource potential and environmental balance of economic development of agrarian enterprise was carried out. All factors that provide attainment of environmentally balanced mission were analyzed.

2. The aims of enterprise were elaborated and checked on positivity. It was proved, that all aims and correspondent condition that provide their attainment are devoid of conflict. Thus, the "tree of aims" itself is devoid of conflict and can become the base for establishing the mission of studied enterprise. The providing conditions were established and the priority of their attainment was selected.

3. The "tree of aims" for realization of environmentally balanced strategy of PRAE Agrofirm "Mir" was built.

4. The mission of agrarian enterprise was formed. Mission of PRAE AF "Mir" is: "Satisfaction of food, taste, esthetical needs of consumers of production, offering the high-quality and relatively cheap assortment of agricultural production and capitalization of $5 \%$ of annual profit for renewal of technological equipment, also support of favorable environment, infrastructure and conditions for labor, leisure and physical development of rural population".

5. Theoretical bases of grounding of environmentally balanced strategy of development of agricultural enterprise for improvement of its complex development were studied in details. The aim of enterprise it is a solution of problems, connected with establishing of issue of the high-quality agricultural production, creation of the new workplaces and culture of production that preserves and protects environment.

6. The regional features of environmental balance of economic development of enterprise are taken into account.

For providing environmentally balanced economic activity the following conditions are needed: presence of the necessary natural-resource potential and eco-friendly conditions in the functioning zone of enterprise, access to financial and credit resources, presence of qualified staff, able to ecologization of economic activity, sufficiently high technical and technological level of specialists, system of qualification improvement and probation.

Based on the favorable market situation agricultural enterprise can actively increase its segment on the market and using its financial possibilities and present resource-saving technologies can produce competitive, eco-friendly and organic products under conditions of irrigated agriculture.

\section{References}

[1] Martinenko, V. P. (2004). Ekonomichnij mehanizm upravlinnja stijkim rozvitkom promislovih pidpriemstv. Mehanizm reguljuvannja ekonomiki, 4, 191-200.

[2] Mel'nik, L. G., Shapochka, M. K., Balac'kij, O. F. (2006). Osnovi ekologii. Ekologichna ekonomika ta upravlinnja prirodokoristuvannjam. Sumi: Universitets'ka kniga, 759.

[3] Burkinskij, B. V., Stepanov, V. N., Harichkov, S. K. (2005). Jekonomiko-jekologicheskie osnovy regional'nogo prirodopol'zovanija i razvitija. Odessa: Feniks, 575.

[4] Eds. Halushkinoyi, T. P. (2008). Ekolohichnyy audyt: teoriya ta praktyka. Odesa: TOV «INVATs», 47.

[5] Hranovs'ka, L. M. (2009). Ekoloho-zbalansovane pryrodokorystuvannya v umovakh polifunktsional'nosti terytoriy. Vydavnytstvo KhDU, 414.

[6] Mel'nyk, L. H. (2006). Ekolohichna ekonomika. Sumy: VTD «Universytet·s'ka knyha», 367.

[7] Harichkov, S. K., Sadchenko, E. V., Ivanchenkova, L. V. (2009). Jekologicheskij biznes i reinzhiniring okruzhajushhej sredy. Ekonomicheskie innovacii, 35, 447-459.

[8] Shevchuk, V. Ya., Satalkin, Yu. M., Bilyavs'kyy, H. O., Navrots'kyy, V. M. Het'man, V. V. (2004). Ekolohichne upravlinnya. Kyiv: Lybid', 432.

[9] Herasymchuk, Z. V., Halushchak, V. L. (2006). Polityka rozvytku problemnykh rehioniv: metodolohichni zasady formuvannya ta realizatsiya. Luts'k: Nadstyr» ya, 220.

[10] Lukyanykhin, V. O. (2002). Ekolohichnyy menedzhment u systemi upravlinnya zbalansovanym rozvytkom: monohrafiya. Sumy: VTD «Universytet·s'ka knyha», 314.

[11] Trehobchuk, V. M., Paskhaver, B. Y., Yuzefovych, A. E. (2005). Pro dovhostrokovu stratehiyu staloho rozvytku ahropromyslovoho. Ekonomika APK, 7, 3-11. 